\title{
The Crystal Structure of $\mathrm{Mo}_{5} \mathrm{Si}_{3}$ and $\mathrm{W}_{5} \mathrm{Si}_{3}$
}

\author{
BERTILARONSSON
}

\author{
Institute of Chemistry, University of Uppsala, Uppsala, Sweden
}

\begin{abstract}
The structure of $\mathrm{W}_{5} \mathrm{Si}_{3}$ has been determined using single crystal data. The elementary cell is body-centered tetragonal with 4 formula units in the cell. The space-group is $D_{4 \mathrm{~h}}^{18}-I 4 / \mathrm{mcm}$. The tungsten atoms occupy one 16-fold and one 4-fold position while the Si-atoms occupy one 8-fold and one 4-fold position.

The relations between the $\mathrm{W}_{5} \mathrm{Si}_{3}$-structure and the $D 8_{8}$ - and $\mathrm{Fe}_{3} \mathrm{P}$. structures are discussed.
\end{abstract}

$\mathrm{T}$

The silicides of the transition metals have been extensively investigated in the recent years. A review of the structures and properties of these substances has been given by Nowotny and Parthé ${ }^{1}$. As was mentioned in an earlier paper ${ }^{2}$ some attention has been devoted to these silicides at this institute, also, and in particular to the phases " $\mathrm{Mo}_{3} \mathrm{Si}_{2}$ " and " $\mathrm{W}_{3} \mathrm{Si}_{2}$ ", the existence of which was first reported by Brewer and collaborators ${ }^{3}$.

From powder photographs Schönberg ${ }^{4}$ found the elementary cell of these phases to be bodycentered tetragonal with the dimensions $a=9.62 \AA$, $c=4.90 \AA\left(\mathrm{Mo}_{5} \mathrm{Si}_{3}\right)$ and $a=9.64_{5} \AA, c=4.97 \AA\left(\mathrm{W}_{5} \mathrm{Si}_{3}\right)$.

A determination of the density of the Mo-phase gave the value of 8.2. This indicated that the composition of the phases should be $\mathrm{Mo}_{5} \mathrm{Si}_{3}$ and $\mathrm{W}_{5} \mathrm{Si}_{3}$ with four formula units in each elementary cell. There is a conspicuous similarity between these cells and that of $\mathrm{Fe}_{3} \mathrm{P}$, and one reason why this investigation was started was to see whether or not this similarity depended on any deeper resemblances between the two structures.

In a footnote in the above mentioned review ${ }^{1}$ it is reported that the cell dimensions have also been determined by $\mathrm{H}$. Schachner, who has found the additional isomorphous phases " $\mathrm{Cr}_{3} \mathrm{Si}_{2}$ " and " $\mathrm{Nb}_{3} \mathrm{Si}_{2}$ ".

In the following this structure type is referred to as the " $\mathrm{W}_{5} \mathrm{Si}_{3}$ type" because the single crystal data were obtained from a crystal of $\mathrm{W}_{5} \mathrm{Si}_{3}$.

\section{EXPERIMENTAL}

The silicides were prepared from weighed amounts of silicon and transition metal by sintering in a carbon tube furnace and melting in an arc furnace in an atmosphere of argon. Powder photographs were taken in a camera of the Guinier type, using CuKa-

Acta Chem. Scand. 9 (1955) No. 7 
rediation. Good single crystals of the tungsten phase were obtained in the semple melted in the arc furnace. A single crystel of suitable size was picked out and Weissenberg photographs were taken around the $c$-exis, using MoK-radiation. The layer lines $0-5$ were recorded. The intensities were visually estimated. The Patterson-sections $P(x y 0)$ and $P(x y 1 / 4)$ and the preliminary Fourier projection $\varrho(x y)$ were computed on the HäggLaurent machine ${ }^{b}$. The final Fourier projection in which higher wave numbers were used than this machine could handle was made with the aid of the Beevers-Lipson strips.

\section{DETERMINATION OF THE STRUCTURE}

As $h k l$-reflexes were only observed when $h+k+l=2 \mathrm{n}$ and $0 k l$-reflexes only when $k=2 \mathrm{n}$ and $l=2 \mathrm{n}$, the possible space-groups were $D_{4 \mathrm{~h}}^{18}-I 4 / \mathrm{mcm}$, $C_{4 \mathrm{v}}^{10}-I 4 \mathrm{~cm}$ and $D_{2 \mathrm{~d}}^{10}-I \overline{4} c 2$.

Judging from the vector concentrations in the Patterson-space, $D_{4 \mathrm{~h}}^{18}-I 4 /$ $m \mathrm{~cm} *$ was considered to be the most probable one. A closer analysis of the $P(x y z)$ function showed that by placing $16 \mathrm{~W}_{\mathrm{I}}$ in $16(k)$ with $x=0.074$ and $y=0.223$ and $4 \mathrm{~W}_{\mathrm{Ir}}$ in $4(b)$ the positions and relative heights of all the strong vectors could be explained. Good agreement was also obtained between observed and calculated intensities .

Space considerations showed that the only $\mathrm{Si}$-positions that would give reasonable interatomic distances were $8 \mathrm{Si}_{\mathrm{I}}$ in $8(h)$ with $x=0.17$, and $4 \mathrm{Si}_{\mathrm{II}}$ in $4(a)$. The shortest $\mathrm{Si}_{I}-\mathrm{W}_{\mathrm{I}}$ vector would in that case have a very high multiplicity and it is indeed found in the Patterson-space with the expected relative height.

Finally, the Fourier projection $\varrho(x y)$ was evaluated (Fig. 1). An empirical correction for absorption and thermal movement has been applied. This correction did not change the parameters of the $\mathrm{W}$ atoms but gave a somewhat more even background. It is seen from the projection that there are small but evident indications of maxima where Si-atoms are expected to be situated. The final atomic positions are**.

\begin{tabular}{|c|c|c|c|c|c|c|}
\hline & & & & $x$ & $y$ & $z$ \\
\hline $\begin{array}{r}16 \\
4 \\
8 \\
4\end{array}$ & $\begin{array}{l}\mathbf{W} \\
\mathbf{W} \\
\mathbf{S i} \\
\mathbf{S i}\end{array}$ & $\begin{array}{l}\text { in } \\
\text { in } \\
\text { in } \\
\text { in }\end{array}$ & $\begin{array}{r}16(k) \\
4(b) \\
8(h) \\
4(a)\end{array}$ & $\begin{array}{l}0.074 \\
0 \\
0.17 \\
0\end{array}$ & $\begin{array}{l}0.223 \\
1 / 2 \\
0.67 \\
0\end{array}$ & $\begin{array}{r}0 \\
1 / 4 \\
0 \\
1 / 4\end{array}$ \\
\hline
\end{tabular}

\section{THE STRUCTURE}

It is well known $1,3,6$ that the structures of the transition metal silicides and borides reveal a strong tendency to form nonmetal-nonmetal bonds. This tendency is clearly manifested in the $\mathrm{W}_{5} \mathrm{Si}_{3}$-structure where the $\mathrm{Si}_{\mathrm{II}}$ atoms form straight chains with a $\mathrm{Si}-\mathrm{Si}$ distance of $2.48 \AA$ parallel to the $c$-axis. The fact that $\mathrm{Si}-\mathrm{Si}$ bonds have been created here may be the reason why $\mathrm{W}_{5} \mathrm{Si}_{3}$ crystallizes in this structure and not in the $D 8_{8}$-structure ${ }^{7}$, which

\footnotetext{
* Quite recently this space-group has also been suggested by E. Parthé et al. ${ }^{11}$

** This structure is identical with that given in Ref. ${ }^{2}$, but a space group of higher symmetry has been chosen.
} 


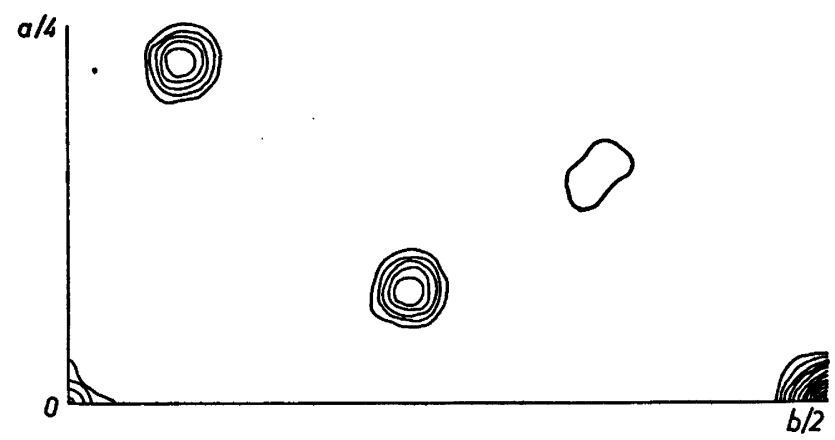

Fig. 1. Final Fourier projection $\varrho(x y)$. Contours are drawn at intervals of approximately $40 e A^{-2}$ (around the $W$-atoms $80 e A^{-2}$ ). $1 / 8$ of the unit cell is shown.

corresponds to the same composition. There are, however, certain similarities between the two structure types.

As is seen from Table 1 , where the environment of each atom is given, the coordination numbers of the metal atoms are the same in the two structures, but that of Si has increased by one in $\mathrm{W}_{5} \mathrm{Si}_{3}$. The characteristic straight chains of metal atoms with very close contact which are found among the silicides with the $D 8_{8}$ - $^{-}$and $\mathrm{W}_{3} \mathrm{O}^{8}$-structure are also found here. Fig. 2 shows two cells taken from the $\mathrm{W}_{5} \mathrm{Si}_{3}$-structure in order to illustrate the straight chains mentioned and their environment.

The degree of close-packing is slightly greater in $\mathrm{W}_{5} \mathrm{Si}_{3}$, the volume occupied by each atom being $1-2 \%$ less than in the $D 8_{8}$-structure.

Thus, there are common features in the two structures and the differences in lattice energy between them is probably small. When Mo and Si were sintered in a carbon tube furnace $\left(\sim 1800^{\circ}\right)$ approximately equal amounts of the ternary Mo-Si-C phase ${ }^{9,10}\left(D 8_{8}\right.$-structure) and the $\mathrm{Mo}_{5} \mathrm{Si}_{3}$-phase were obtained
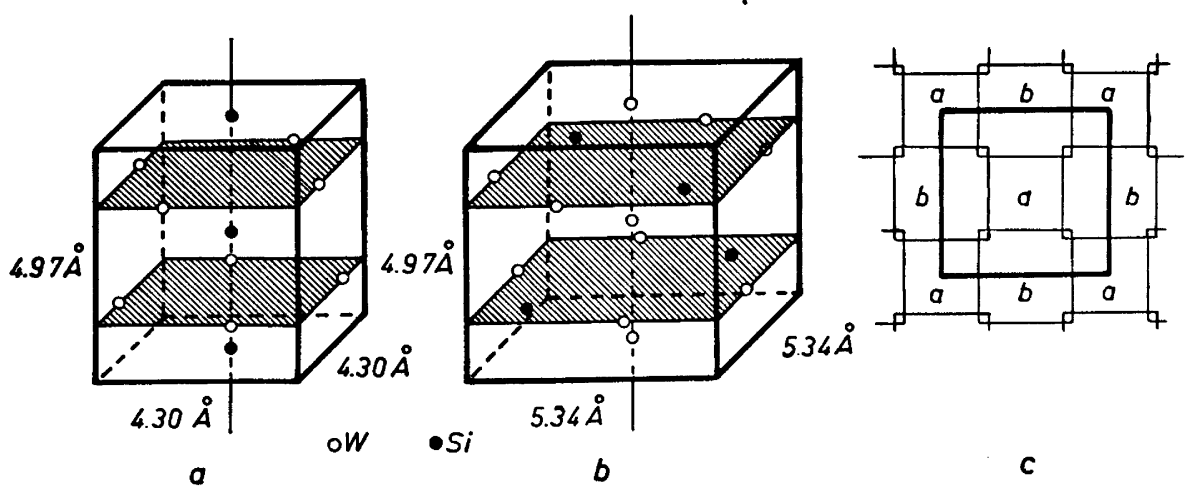

Fig. 2. a. Surroundings of a SiII-chain. b. Surroundings of a WI-chain. c. A projection on the basal plane of the cells $a$ and $b$ showing their relative positions in the unit cell.

Acta Chem. Scand. 9 (1955) No. 7 
Table 1.

\begin{tabular}{|c|c|c|}
\hline & Interatomic distances in $\AA$ & $\begin{array}{l}\text { Environment of the } \\
\text { corr. atom in the } \\
D 8_{8} \text {-str. }\end{array}$ \\
\hline $\begin{array}{r}\text { WI }-9 \mathrm{~W} \\
-6 \mathrm{Si} \\
\mathrm{WII}_{\mathrm{II}}-10 \mathrm{~W} \\
-4 \mathrm{Si} \\
\mathrm{Sir}^{-10} \mathrm{~W} \\
(-2 \mathrm{Si} \\
\operatorname{SiII}-8 \mathrm{~W} \\
-2 \mathrm{Si}\end{array}$ & $\begin{array}{l}2.77 ; 2.86(2) ; 3.20(2) ; 3.21(2) ; 3.03(2) \\
2.5 ; 2.6(3) ; 2.8(2) \\
2.48(2) ; 3.03(8) \\
2.6(4) \\
2.5(2) ; 2.6(4) ; 2.8(4) \\
3.2(2) .) \\
2.58(8) \\
2.48(2)\end{array}$ & $\begin{array}{lll}\text { MerI } & -10 & \mathrm{Me} \\
& =5 & \mathrm{Si} \\
\mathrm{MeI} & -8 & \mathrm{Me} \\
& =6 & \mathrm{Si} \\
\mathrm{Si} & -9 & \mathrm{Me} \\
& (-2 & \mathrm{Si}) \\
\mathrm{Si} & =9 & \mathrm{Me} \\
& (-2 & \mathrm{Si})\end{array}$ \\
\hline
\end{tabular}

(only $0.2-0.3 \%$ by weight of carbon was found in the sample). However, when annealed in vacuo $\left(400^{\circ}-1100^{\circ}\right)$ a complete transformation to the tetragonal phase occurred. The stabilizing effect of nonmetals with small atomic radius on the $D 8_{8}$-structure has been discussed in the Refs. ${ }^{1,9,10}$.

No significant similarities between $\mathrm{Fe}_{3} \mathrm{P}$ and $\mathrm{W}_{5} \mathrm{Si}_{3}$ have been found.

Acknowledgements. The author wishes to thank professor G. Hägg for his encouraging interest and many valuable suggestions. Thanks are also due to Mr. N. Schönberg for introducing the author to this interesting field of crystal chemistry.

\section{REFERENCES}

1. Nowotny, H. and Parthé, E. Planseeber. 2 (1954) 34.

2. Aronsson, B. Acta Chem. Scand. 9 (1955) 137.

3. Brewer, L., Searcy, A. W., Templeton, D. H. and Dauben, C. H. J. Am. Chem. Soc. 33 (1950) 291.

4. Private communication.

5. Hägg, G. and Laurent, T. J. Sci. Instr. 23 (1946) 155.

6. Kiessling, R. Fortschr. Chem. Forsch. 3 (1954) 41.

7. Ámark, K., Borén, B. and Westgren, A. Metallwirtschaft 15 (1936) 835; see also Strukturbericht IV:137.

8. Hägg, G. and Schönberg, N. Acta Cryst. 7 (1954) 351.

9. Nowotny, H., Parthé, E. Kieffer, R. and Benesovsky, F. Monatsh. 85 (1954) 255.

10. Brewer, L. and Krikorian, O. UCRL 2544, University of California 1954.

11. Parthé, E., Schachner, H. and Nowotny, H. Monatsh. 86 (1955) 182.

Received April 25, 1955. 